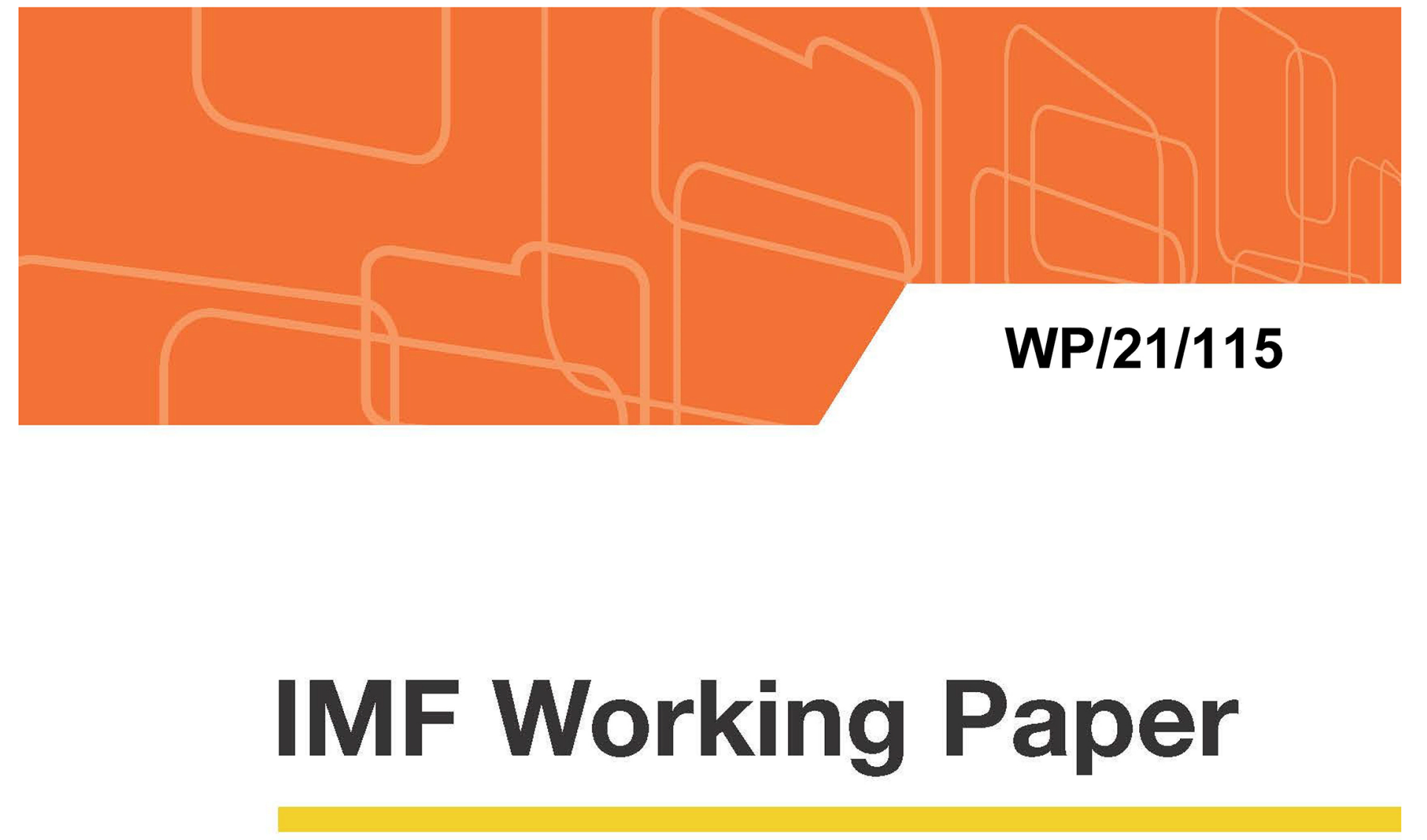

\title{
SDG Financing Options in Rwanda: A Post-Pandemic Assessment
}

by Victor Duarte Lledo and Roberto A. Perrelli

IMF Working Papers describe research in progress by the author(s) and are published to elicit comments and to encourage debate. The views expressed in IMF Working Papers are those of the author(s) and do not necessarily represent the views of the IMF, its Executive Board, or IMF management. 


\title{
IMF Working Paper
}

Fiscal Affairs Department

\author{
SDG Financing Options in Rwanda: A Post-Pandemic Assessment \\ Prepared by Victor Duarte Lledo and Roberto A. Perrelli ${ }^{1}$ \\ under the guidance of Dora Benedek and Alexander F. Tieman \\ Authorized for distribution by Abdelhak Senhadji \\ April 2021
}

\section{IMF Working Papers describe research in progress by the author(s) and are published to elicit comments and to encourage debate. The views expressed in IMF Working Papers are those of the author(s) and do not necessarily represent the views of the IMF, its Executive Board, or IMF management.}

\begin{abstract}
This paper uses a novel macroeconomic framework to identify policy and financing options to help Rwanda achieve its sustainable development goals (SDGs). Under current policies, Rwanda would meet its SDGs right after 2050. Active policies that combine fiscal reforms and higher private sector participation could fulfill more than one third of Rwanda's postpandemic SDG financing gap, enabling the country to meet its SDG targets by 2040. For Rwanda to meet its SDGs by 2030, active policies would need to be complemented with about $13 \frac{3}{4}$ percentage points of GDP in additional resources annually until then.

JEL Classification Numbers: Q01, H11, H20, H87, O23, I15, I25, F35

Keywords: Sustainable Development Goals, Development, Fiscal Policy, Structural Reform Author's E-Mail Address: VLledo@imf.org and RPerrelli@,imf.org

\footnotetext{
${ }^{1}$ This paper was written as technical background to the IMF Staff Discussion Note "A Post-Pandemic Assessment of Sustainable Development Goals". We are grateful for comments from Olusegun Akanbi, David Baar, David Bartolini, Svetlana Cerovic, Hua Chai, Il Jung, Yujin Kim, Narine Nersesyan, Baoping Shang, and Mauricio Soto.
} 


\section{Content}

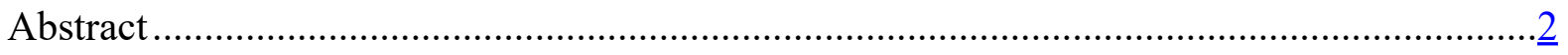

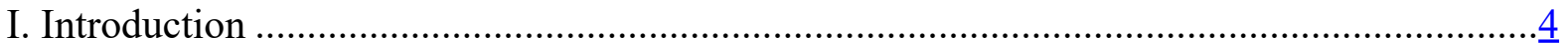

II. A Dynamic Financing Framework for Sustainable Development Goals ........................... $\underline{5}$

III. Rwanda’s SDG Financing: Pre-Pandemic Situation..................................................... 7

A. Pre-Pandemic Development Progress and Challenges ......................................

B. Pre-Pandemic Financing Gaps .........................................................................

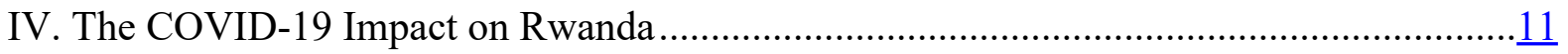

V. Rwanda's SDG Financing: Post-Pandemic Gap and Policy Options ................................13

VI. SDG Financing: The Perils of Scarring ...................................................................

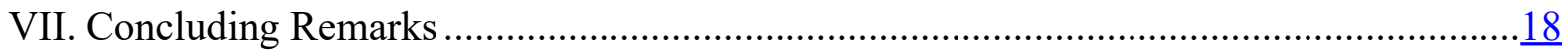

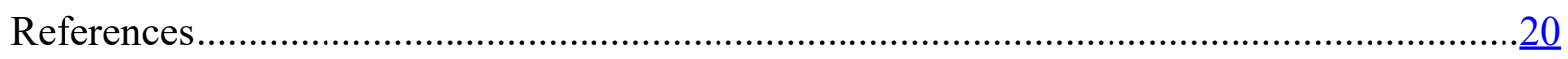

\section{Box}

Box 1. Rwanda's COVID-19 Crisis Response .................................................................

\section{Figures}

Figure 1. Rwanda: Performance across Selected SDGs .................................................... $\underline{8}$

Figure 2. Rwanda: SDG Needs according to IMF Costing Mission...................................... $\underline{8}$

Figure 3: Rwanda: Pandemic-Related Real Output Losses, 2018-25 ................................13

Figure 4: Rwanda: Gross Nominal Public Debt Paths, 2018-30 ........................................13

Figure 5. Rwanda: Changes in Available Fiscal Space to Invest in SDGs, 2020-30 .............14

Figure 6. Rwanda: Impact of MTRS on Tax Revenues, 2018-30 ...................................14

Figure 7. Rwanda: Impact of Scarring on Human Capital Per Worker, 2018-50 .................17

Figure 8. Rwanda: Impact of Scarring on Real GDP Growth Rates, 2018-50 ....................17

Figure 9. Rwanda: Impact of Active Policies on Per Capita Income, 2018-50 ..................17

Figure 10. Rwanda: Impact of Active Policies on Human Capital Per Worker, 2018-50 ......17

\section{Tables}

Table 1. Rwanda: Selected Economic Indicators ............................................................ 9

Table 2. Rwanda: Dynamic Financing Framework Scenarios, 2020-50 (Pre-COVID)..........10

Table 3. Rwanda: Additional Grants Needed to Meet 2030 SDGs .....................................14

Table 4. Rwanda: Dynamic Financing Framework Scenarios, 2020-50 (Post-COVID) ........16 


\section{INTRODUCTION}

The COVID-19 pandemic has significantly impacted the global development agenda. The pandemic has plunged the world into a deep recession, pushing millions of people into extreme poverty and exacerbating pre-existing inequalities in access to basic services within and across countries. Moreover, the pandemic may cause lasting economic scars that reduce potential growth (World Bank, 2020 and 2021, IMF 2020). Low-income and developing countries (LIDCs) and sub-Saharan African economies (SSA) have been hit particularly hard. Responses to the pandemic have significantly stretched public finances, raising debt levels to historical highs, and leaving LIDCs and SSA particularly exposed after a decade-long process of debt accumulation (IMF 2020). The combination of rising development needs and limited fiscal space risks making sustainable development goals (SDGs) unachievable by the 2030 target-year in some countries.

Meeting the SDGs will require renewed commitment to pro-SDG policies from all stakeholders informed by clear financing strategies. Government resources - already limited before the pandemic - have been further spread thin. The stakes for structural reforms to boost potential growth, mobilize domestic resources, and improve the efficiency of spending have been raised further. National authorities with support from development partners will need to refresh strategies to facilitate private investment in SDGs. Steadfast implementation of public policies may not be sufficient to raise sufficient funding to meet the SDGs by 2030 if not complemented by renewed efforts by development partners to scale up aid, especially on concessional terms. Against this background, the assessment of financing options to close SDG gaps becomes a critical starting point to muster broad-based support for development in the pandemic aftermath.

The present paper supports this initiative by introducing a dynamic financing framework that allows policymakers to assess the inter-temporal coherence of their development strategies. Following Benedek and others (2021), this framework quantifies SDG financing gaps and sheds light on the feasibility of meeting SDGs within a given projection horizon. The framework is flexible enough to permit the assessment of different financing options in alternative macroeconomic scenarios and using various policy levers, including domestic revenue mobilization, private sector funding, and support from the international community. In particular, the framework gauges whether and how the SDGs can realistically be achieved by 2030 under current policies and, if not, by when they could be. The framework also allows for assessing the extent of economic scarring by estimating the pandemic impact on long-term growth in stylized scenarios.

We apply the framework to the case of Rwanda's SDG financing gap. Rwanda is well-known for achieving a remarkable progress in social and economic development over the past two decades (IMF, 2019, Redifer and others, 2020). Poverty levels reduced fast, falling from 60 to 38 percent, and its human development score doubled between 1990 and 2019. Despite its progress, Rwanda still faced serious development challenges at the onset of the pandemic. Poverty remained high, nutrition indicators disappointed, and access to quality healthcare, 
clean water, sanitation, and electricity remained limited for a broad segment of the population. A pre-pandemic assessment of spending requirements estimated Rwanda would need substantial additional spending to achieve the 2030 SDGs in the critical areas of health, education, water and sanitation, roads, and electricity. ${ }^{2}$ The pandemic made a challenging situation worse. Up to $1 / 2$ million citizens could fall into poverty in 2021 ; access to essential health services have been significantly disrupted; and an estimated 3.5 million children remained out of school for most of 2020 (World Bank, 2021). Fiscal space to tackle the SDGs has been further constrained. Growth and tax revenues plummeted following the pandemic, while the government increased expenditures to mitigate the ensuing health and economic crisis. Public debt surged as a result. Debt-to-GDP ratios are projected to increase by more than 10 percentage points by end-2021, raising the risk of debt distress from low to medium (IMF, 2021). As a result, the fiscal space to spend on SDG needs has narrowed.

The dynamic financing framework shows that the pandemic has widened Rwanda's financing gap to meet its 2030 SDG targets by about 5 $\frac{1}{2}$ percentage points of GDP. More than half of it is explained by the lower post-pandemic nominal GDP level. Under current policies, Rwanda would meet its SDGs right after 2050. If the country were able to mobilize all funding needed to close its pre-COVID SDG financing gap by 2030, Rwanda would still need an additional five years to meet them (i.e. by 2035) in the post-COVID environment. Active policies that combine fiscal measures and higher private sector participation could fulfill more than one third of Rwanda's post-pandemic SDG financing gap. Nevertheless, even in the scenario with active policies, the pledge to meet its SDGs by 2030 would require about $13 \frac{3}{4}$ percentage points of GDP in additional resources annually until then.

The paper is organized as follows. Section II lays out the dynamic financing framework. Section III describes Rwanda's pre-pandemic situation and development challenges. Section IV assesses the impact of the pandemic in Rwanda. Section V discusses policy and financing options. Section VI revisits these options assuming the pandemic reduces long-term output (economic scarring). Section VII concludes with some policy recommendations.

\section{A DYNAMIC FinANCING FramewORK FOR SUSTAINABLE DEVELOPMENT GoAlS 3}

The dynamic financing framework consists of a set of accounting identities covering the real, fiscal, and external sectors to ensure macroeconomic consistency. The framework focuses on the contributions of public and private funding to achieve SDGs in five key areas (education, health, roads, electricity, and water and sanitation). Importantly, economic growth is determined endogenously and adopted policies have a feedback effect on a country's SDG financing gap over the projection horizon (2020-50).

\footnotetext{
${ }^{2}$ Using a static costing model, Gaspar et al (2019) estimate needs in the order of 18.7 percent of GDP per year.

${ }^{3}$ For a detailed description of the model, see Bartolini and Hellwig (2021).
} 
Output follows an augmented neoclassical growth model based on the Debt, Investment and Growth (DIG) framework developed by the IMF to address the public investment-growth nexus and fiscal adjustments in low-income and developing countries (Buffie et al., 2012, Berg et al. 2012). The production function is given by:

$$
Y_{i t}=A_{i t}\left(K_{i t, G . n o n b a n k}+\theta_{i t} K_{i t, G . b a n k}\right)^{\beta} K_{i t, P}^{\alpha}\left(L_{i t} h_{i t}^{\gamma}\right)^{1-\alpha}
$$

where the subscripts $i$ and $t$ refer to country and year, respectively. In equation (1), $A$ denotes total factor productivity, $K_{G}$ is public capital, $K_{P}$ is private capital, $L$ is labor, and $h=\mathrm{H} / \mathrm{L}$ is the stock of human capital per worker. To capture the possibility of public goods financed with private resources (Irwin et al., 2018), we decompose public capital into "bankable" $\left(K_{\text {G.bank }}\right)$ and "non-bankable" (KG.nonbank), with the latter consisting exclusively of public resources and the former being associated to an efficiency parameter $\theta \geq 1$ (see IMF, 2015). The elasticities $\alpha, \beta$, and $\gamma$ range between zero and one. Following Atolia et. al. (2019) and Buffie et. al. (2020), we assume the production function features increasing returns to scale.

We use the standard law of motion for the accumulation of public and private capital widely available in the literature. The stock of physical capital $K$ in the economy $i$ increases with investment $I$ and declines with depreciation $\delta^{K}$ at each period of time $t$,

$$
K_{i t}=\left(1-\delta_{i t}^{K}\right) K_{i t-1}+\epsilon_{i t} I_{i t}
$$

where $\epsilon$ is a country- and time-specific efficiency parameter bounded between zero and one. Importantly, the country's decision on how much to invest in SDG versus non-SDG physical capital at each period of time makes a substantial difference in terms of SDG financing gap.

Following Atolia et. al. (2019), the framework assumes that human capital accumulation declines with depreciation $\delta^{H}$ and increases with previous period investment in schooling $S$ at a rate $\omega \in(0,1)$ at which students move into the labor force:

$$
H_{i t}=\left(1-\delta_{i t}^{H}\right) H_{i t-1}+\omega_{i t} S_{i t-1}
$$

Health spending affects human capital through its impact on schooling $S$ :

$$
S_{i t}=\left(1-\omega_{i t}\right) S_{i t-1}+\left(\rho_{i t} T_{i t-1}\right)^{\phi} N_{i t-1}^{\gamma}
$$

where $T$ is the total spending on health and education at each period, $\rho>0$ is an efficiency parameter, $\phi$ is the elasticity of human capital to spending on health and education, $N$ is the share of school-age population in that economy, and $\gamma$ is the elasticity of schooling to the size of the school-age population. ${ }^{4}$

\footnotetext{
${ }^{4}$ In addition to its impact on schooling, health spending could also boost the productivity of working-age population, for example, by reducing sick days as well as the time to care for ill children and elderly.
} 
To calibrate the production function, we use the latest data on the stock of physical capital (IMF Fiscal Affairs Department's Investment and Capital Stock database) and demographic projections from the United Nations' World Population Prospects (United Nations, 2019). The remaining macroeconomic variables are collected from the IMF World Economic Outlook database and through surveys applied to Rwanda desks. The 2030 SDG targets are based on Gaspar et. al. (2019) and adjusted according to the latest economic and financial developments in Rwanda.

\section{RWAnda's SDG Financing: Pre-Pandemic Situation}

\section{A. Pre-Pandemic Development Progress and Challenges}

Rwanda has made remarkable progress in social and economic development over the past two decades (IMF, 2019; Redifer 2020). Since 1995, the country has experienced rapid and inclusive growth by incorporating the millennium development goals (MDGs) into its national development plans. GDP per capita more than tripled between 2000 and 2019. Poverty levels reduced fast, falling from 60 to 38 percent, and its human development score doubled between 1990 and 2019. Ultimately, Rwanda achieved all but one of its MDGs. Its current outcomes are above the median of peers in health, education, water and sanitation, and infrastructure (Figure 1). In particular, healthcare has benefited from extensive primary care by rural clinics and enrollment in education is nearly universal at the primary level, albeit less than 40 percent at the secondary level.

Rwanda is strongly committed to ensuring that its 2030 sustainable development goals are understood and owned domestically and across stakeholders. To this end, the authorities have developed a long-term strategy ("Vision 2050") aimed at achieving upper-middle-income status by 2035 (a per capita income of US $\$ 4,035$ ) and high-income status by 2050 (a per capita income of US\$12,476). The Vision is initially being implemented with a 2017-24 "National Strategy for Transformation" (NST1), into which the SDGs have been integrated. Specifically, prior to the COVID-19 pandemic, the strategy aimed to increase total annual investment from 23 percent of GDP in 2017 to 31 percent in 2024. Public investment, including the Government's part in public-private partnerships (PPPs), was set to increase gradually from 8.3 percent of GDP in 2017 to 9.9 percent in 2024. An important share of this increase would be directed towards education and human capital. The strategy also specifies that these increases would largely be funded from higher tax and non-tax revenues.

Despite its remarkable progress on several fronts, Rwanda faced serious development challenges at the onset of the pandemic. Poverty remained high and nutrition indicators disappointed; stunting affected many children, hampering early childhood progress, and in turn affecting learning outcomes; access to qualified healthcare providers was low, and access to clean water and sanitation remained difficult. The electricity sector had excess ongrid capacity but only 46 percent of households were connected to the grid. 
Figure 1. Rwanda: Performance across Selected SDGs (Indices)

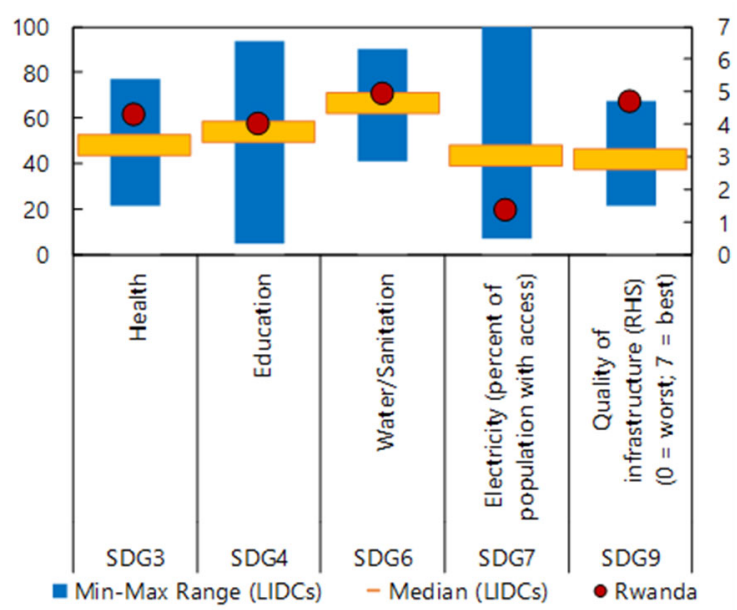

Sources: Gaspar et al (2019), SDG Index and Dashboards Report 2018, World Economic Forum.

Note: LIDCs = low-income developing countries;

$\mathrm{RHS}=$ right scale.
Figure 2. Rwanda: SDG Needs according to IMF Costing Mission

(percent of 2030 GDP)

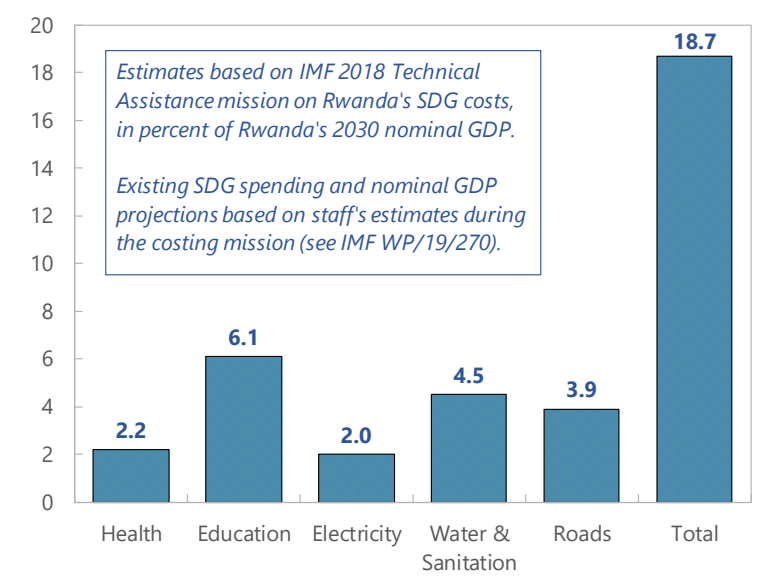

Sources: Gaspar et al (2019),

Based on a static costing model, Gaspar et. al. (2019) estimated Rwanda would need additional annual spending of 18.7 percent of GDP to achieve the 2030 SDGs in the critical areas of health, education, water and sanitation, roads, and electricity (Figure 2).

\section{B. Pre-Pandemic Financing Gaps}

Rwanda's policies were sound and economic performance strong at the onset of the pandemic in early 2020. The authorities' policies were supported by the IMF's Policy Coordination Instrument (PCI) since mid-2019 and focused on creating budget space for the implementation of Rwanda's NST1 while preserving fiscal sustainability (IMF 2019). ${ }^{5}$ The authorities also aimed at regaining momentum on domestic revenue mobilization and enhancing fiscal transparency. By the time of the PCI First Review in October 2019, a booming construction sector, robust services activity, and strong agricultural output led staff to upgrade its 2019 real GDP growth rate estimate to 8.5 percent, and to project growth at about the same pace for the following years (IMF 2020a, Table 1). Inflation expectations were anchored around 5 percent. The overall fiscal deficit was within the adjusted program

\footnotetext{
${ }^{5}$ Rwanda's PCI-supported program was approved in June 2019 (IMF 2019) to support the implementation of the country's National Strategy for Transformation (NST). The four pillars of the PCI are: (i) creating budget space for the implementation of the NST while preserving fiscal and debt sustainability; (ii) improving fiscal transparency, including the identification and management of potential government liabilities, (iii) regaining momentum on domestic revenue mobilization; and (iv) supporting the implementation of the National Bank of Rwanda's new interest rate-based monetary policy framework.
} 
rule of 5.5 percent of GDP and public debt (including government guarantees) was projected to remain below the Eastern African Community debt convergence criterion of 50 percent of GDP in net present value (NPV) terms. ${ }^{6}$

The authorities were committed to increase tax revenues. Given Rwanda's investment needs and fiscal rule, mobilizing domestic revenue was necessary to pursue its sustainable development goals. The authorities' strategy was guided by IMF Technical Assistance missions on tax policies and revenue administration with a focus on: (i) streamlining tax incentives (mostly from

Table 1. Rwanda: Selected Economic VAT exemptions), (ii) improving tax compliance (boosting registration and intensifying the use of technology), and (iii) developing a Medium-Term Revenue Strategy (MTRS).

Even so, Rwanda lacked a detailed plan to finance its long-term development goals. To meet its SDGs by 2030, Rwanda needed to invest around 6.1 percent of GDP on education and 2.2 percent of GDP on health per year. Moreover, infrastructure investments of 4.5 percent of GDP on water and sanitation, 3.9 percent of GDP on roads, and 2 percent of GDP on electricity were required (see Prady and Sy (2019) for further details on the SDG costing exercise for Indicators (as of January 2020)

\begin{tabular}{|c|c|c|c|c|}
\hline & 2018 & 2019 & 2020 & 2021 \\
\hline & \multicolumn{4}{|c|}{ (Projected, in percent) } \\
\hline Real GDP & 8.6 & 8.5 & 8.0 & 8.0 \\
\hline \multirow[t]{2}{*}{ Inflation (p.a.) } & 1.4 & 2.3 & 5.4 & 5.0 \\
\hline & \multicolumn{4}{|c|}{ (Projected, in percent of GDP) } \\
\hline Revenues & 24.1 & 23.6 & 23.1 & 22.9 \\
\hline Tax revenues & 16.2 & 16.6 & 16.9 & 16.5 \\
\hline Grants & 4.9 & 4.5 & 4.1 & 4.3 \\
\hline Other & 3.0 & 2.5 & 2.1 & 2.1 \\
\hline Expenditures & 28.8 & 31.9 & 29.0 & 29.2 \\
\hline Current & 15.3 & 15.9 & 14.5 & 14.6 \\
\hline Capital & 11.5 & 12.7 & 12.1 & 12.7 \\
\hline Interest & 2.0 & 3.3 & 2.4 & 1.9 \\
\hline Overall balance & -4.7 & -8.3 & -5.9 & -6.3 \\
\hline Excl. contingent. liab. & -5.0 & -6.7 & -5.7 & -6.4 \\
\hline \multicolumn{5}{|l|}{ PV of total public debt } \\
\hline incl. guarantees & 40.9 & 44.5 & 43.1 & 42.9 \\
\hline
\end{tabular}

Source: IMF Country Report No.20/9, January 2020 Rwanda). Given the limited scope for revenue mobilization and downward trends in official development assistance (ODA) vis-àvis SDG needs, the country would have to rely heavily on a combination of additional public borrowing and private sector participation, including though the "Compact with Africa" and the use of "de-risking" instruments. The authorities expected the costs of the NST1 to be shared (60-40) between the government and the private sector. Last, but not least, enhancing spending efficiency (e.g., through more intensive usage of technology) would also contribute to financing Rwanda's SDGs (IMF 2020a).

\footnotetext{
${ }^{6}$ The fiscal balance under the program, referred as the debt-creating fiscal balance, is defined as the overall balance excluding spending on materialized contingent liabilities already included in the DSA and UN peacekeeping operations. This program-based rule has been suspended and replaced at the outset of the pandemic by a tailored deficit path that accommodates budget needs to fight the pandemic and aims to bring nominal debt-to-GDP below 65 percent of GDP (see IMF Country Report No. 21/1). This debt anchor is deemed to keep the debt within safe levels taking into account Rwanda's history of domestic and external shocks and is consistent with the East African Community debt convergence criterion.
} 
Against this background, we calibrate a dynamic financing framework for Rwanda's SDGs. The pre-pandemic baseline projections are grounded on the global economic assumptions from the January 2020 World Economic Outlook (WEO) and the associated medium-term forecasts for Rwanda at that time. Likewise, the long-term fiscal projections are guided by Rwanda's Debt Sustainability Analysis at that juncture. The adoption of the January 2020 WEO vintage as the pre-COVID benchmark isolates the impact of the COVID-19 pandemic that has reshaped Rwanda's economic outlook, as discussed in the next section.

At the pandemic onset and without any policy changes, under our dynamic financing framework, Rwanda would need additional resources of 15.7 percent of GDP per year to meet its SDGs by 2030. ${ }^{7}$ Absent those resources, Rwanda's SDGs would only be met 15 years later. Our dynamic financing framework scenarios suggest that Rwanda would meet its SDGs by 2045 in the baseline settings (Table 2). Implementing an MTRS that boosts total revenues by 7 percent of GDP could shorten this period by 6 years. ${ }^{8}$ Reallocating 1 percent of GDP of public expenditures towards SDGs while increasing spending efficiency could cut it by 4 years. Combined, these fiscal measures could abridge Rwanda's SDG path by at least 8 years. If on the top of these fiscal measures the authorities could enact policies to attract private investment in development, say to reach the foreign direct investment pace observed in the top quartile of its peers' distribution, Rwanda would be able to meet its SDGs by 2035 . In sum, active policies (fiscal measures and higher private sector participation in SDGs) could lessen Rwanda's SDG gap by more than a half. ${ }^{9}$

\section{Table 2. Rwanda: Dynamic Financing Framework Scenarios, 2020-50 (Pre-COVID)}

\begin{tabular}{|c|c|c|c|c|c|c|c|c|}
\hline \multirow[b]{2}{*}{ Scenario } & \multirow[b]{2}{*}{$\begin{array}{l}\text { SDGs } \\
\text { met by }\end{array}$} & \multirow[b]{2}{*}{$\begin{array}{c}\text { Additional grants } \\
\text { per year } 1 /\end{array}$} & \multicolumn{2}{|c|}{ Per capita income $2 /$} & \multicolumn{2}{|c|}{ Real GDP growth rate 3/ } & \multicolumn{2}{|c|}{ Public debt 1/ } \\
\hline & & & 2030 & 2050 & 2030 & 2050 & 2030 & 2050 \\
\hline A. Pre-COVID baseline settings & 2045 & 0.0 & 1,332 & 3,893 & 7.6 & 7.3 & 53.6 & 53.5 \\
\hline B. Domestic revenue mobilization & 2039 & 0.0 & 1,333 & 4,027 & 7.7 & 7.4 & 53.6 & 52.9 \\
\hline C. Spending reallocation to SDGs & 2041 & 0.0 & 1,406 & 5,297 & 8.7 & 8.4 & 51.7 & 48.3 \\
\hline D. Combined fiscal measures & 2037 & 0.0 & 1,410 & 5,153 & 8.9 & 8.5 & 51.5 & 48.6 \\
\hline E. Private sector participation & 2044 & 0.0 & 1,375 & 4,267 & 8.2 & 7.6 & 52.5 & 52.1 \\
\hline F. Active policies w/o addtl grants & 2035 & 0.0 & 1,451 & 5,679 & 9.4 & 8.6 & 50.5 & 47.4 \\
\hline G. Baseline plus additional grants & 2030 & 15.7 & 1,491 & 5,011 & 9.0 & 7.9 & 50.1 & 50.4 \\
\hline H. Fiscal measures plus grants & 2030 & 9.5 & 1,524 & 6,111 & 9.9 & 8.8 & 49.1 & 46.8 \\
\hline I. Active policies plus grants & 2030 & 7.6 & 1,539 & 6,438 & 10.1 & 8.9 & 48.7 & 46.2 \\
\hline
\end{tabular}

Source: IMF staff estimates

Notes: 1/ In percent of nominal GDP. 2/ In 2018 USD. 3/ In percent.

\footnotetext{
${ }^{7}$ This is akin to say that, in the projections from the dynamic financing model, Rwanda would need additional annual spending of 15.7 percent of GDP to the meet its SDG goals, which are 3 percentage points lower than the previous estimate in Gaspar et al. (2019). This lower estimate is due to higher growth in our baseline scenario than in Gaspar et al.'s framework, reflecting data updates since then. The dynamic nature of our model also allows for a positive feedback on growth from initial infrastructure investment.

${ }^{8}$ The additional tax revenues to finance SDGs, especially health and education, are expected to more than offset their negative impact on output given the central role of human capital in the endogenous growth model.

${ }^{9}$ It is noteworthy to explain that non-concessional resources (e.g. private sector investment in SDG infrastructure) often incur a cost on subsidies and therefore do not have the same impact as traditional grants.
} 


\section{THE COVID-19 IMPACT ON RWANDA}

The pandemic hit Rwanda in mid-March 2020, compounding the effects of natural disasters (heavy rains) earlier in the year. It dampened domestic activity and worsened balance of payments pressures with the disruption of international trade, business travel and tourism, leading to large losses of international reserves. The current account deficit widened due to drops in export receipts, remittances, and grants. Lower tax revenues and new spending pressures implied a large financing gap. The authorities requested IMF assistance in the form of direct budget support under the Rapid Credit Facility (RCF) to address urgent balance of payments needs (IMF, 2020b). The intensification of the crisis led Rwanda to request a second RCF (IMF 2020c). The country also received budget support and health-project resources from the World Bank and other international financial institutions during this period. Finally, Rwanda benefitted from debt relief under the IMF's Catastrophe Containment and Relief Trust.

In response to the pandemic, the authorities launched an ambitious combination of social protection and economic support plans shielding vulnerable citizens and businesses. On the revenue side, the authorities implemented temporary tax deferrals and personal income tax exemptions, softened tax arrears collection, and extended filing and payment deadlines for corporate income taxpayers. In addition, VAT refunds for small and medium enterprises were accelerated. On the expenditure side, cost-effectiveness, better targeting, and preventing crowding-out of other priority areas guided public spending decisions (Box 1).

Notwithstanding these measures, the pandemic reduced economic growth and worsened the fiscal stance, elevating Rwanda's public debt-to-GDP ratio. Real GDP growth rate projections fell to -0.2 percent in 2020 and 5.7 percent in 2021 (from above 8 percent preCOVID) at the time of the $3^{\text {rd }} \mathrm{PCI}$ review in October 2020. Over the medium-term, the country is expected to close the output gap and gradually recover its growth potential. However, this happens at a real GDP level that is on average ten percentage points lower than its pre-COVID trend (Figure 3). Gross public debt (excluding government guarantees) is set to end 2025 some 13 percentage points of GDP higher than in pre-COVID projections, albeit this gap narrows to 6 percentage points of GDP by the end of the decade (Figure 4). Reflecting the post-pandemic outlook, the available fiscal space to invest in SDGs is expected to decline substantially over the medium and long terms. 


\section{BOX 1. RWANDA'S COVID-19 CRISIS RESPONSE}

Rwanda's swift response to the COVID-19 pandemic averted a full-blown health crisis. The government imposed a six-week lockdown and adopted innovative digital solutions for contact tracing, surveillance, prevention, and data visualization. Building on the prepandemic social protection architecture that was grounded on community-based identification and survey information, the authorities used an advanced social data collection and targeting system to support the most vulnerable groups. As a result, Rwanda recorded a limited number of cases and a low fatality rate (see further details in IMF 2020c, 2020d, IMF 2021).

The authorities rolled out two major plans to tackle the pandemic impact on the economy. Rwanda's Social Protection Response and Recovery Plan provided door-to-door food distribution to vulnerable households, cash transfers to informal workers, temporary employment opportunities in labor-intensive public projects, and wider access to health and education services through the provision of subsidized tuition and school material and the construction of sanitation facilities. Rwanda's fiscal and quasi-fiscal support also included, inter alia, subventions to agricultural inputs, subsidized loans to firms in the most affected sectors, and credit guarantees and debt restructuring to firms with potential to recover from the pandemic.

Spending priorities were adjusted to attend higher demand for health and social protection. Pandemic-related health spending amounted to about 1.4 percent of GDP in 2020, mostly allocated to the construction of quarantine facilities and acquisitions of drugs, medical and personal protection equipment. Social protection spending of 0.2 percent of GDP focused on cash transfers and food distribution. To minimize contagion, the authorities invested in sanitation and water facilities in low-income neighborhoods. 
Figure 3: Rwanda: Pandemic-Related Real

Output Losses, 2018-25 (index, 2018=100)

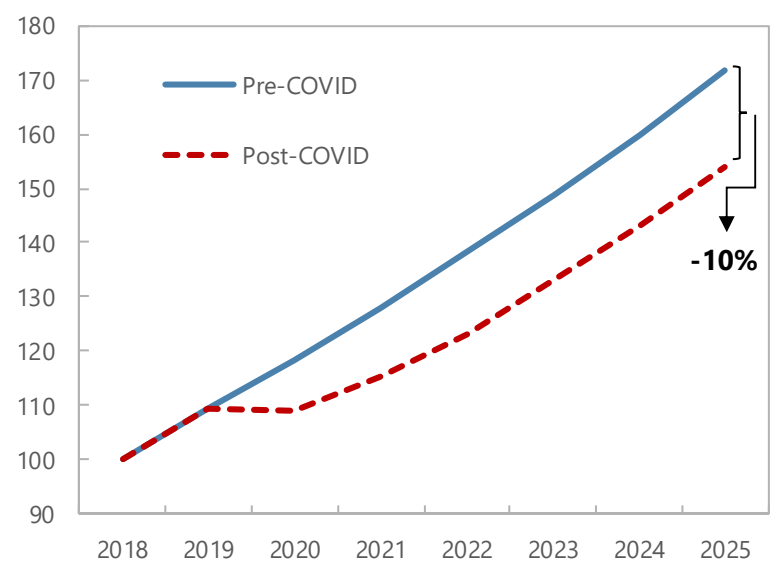

Source: IMF staff estimates
Figure 4: Rwanda: Gross Nominal Public Debt Paths, 2018-30 (percent of GDP)

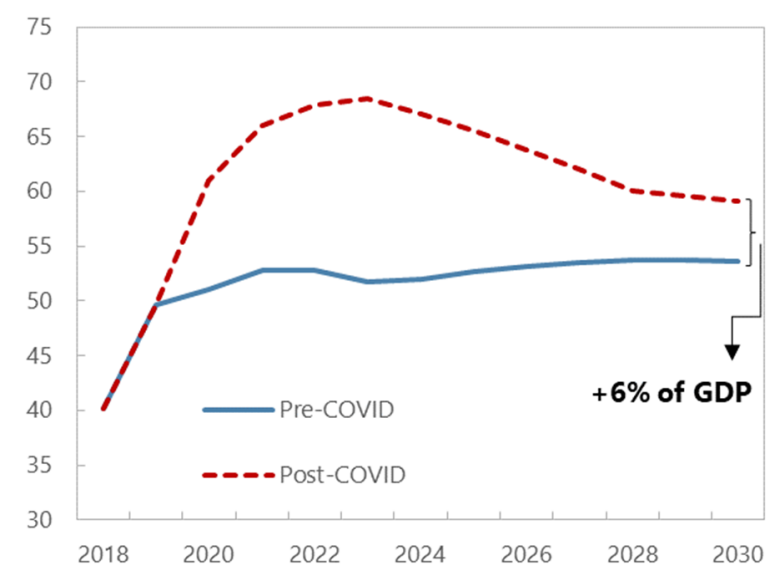

Source: IMF staff estimates

\section{Rwanda’s SDG Financing: Post-Pandemic Gap And Policy Options}

We estimate the pandemic has widened Rwanda's financing gap to meet its 2030 SDG targets by 5.6 percentage points of GDP. More than half of it is explained by the lower postpandemic nominal GDP level. The permanent output loss widens the financing gap to meet some of the SDG targets: specifically, as infrastructure needs (such as the length of the road network or the power generation capacity) remain unchanged, the SDG spending on infrastructure will consume a larger share of the country's post-pandemic (lower) GDP. ${ }^{10}$

Rwanda's annual fiscal space to invest in SDGs over this decade is expected to be, on average, 2.4 percent of GDP lower than pre-pandemic levels (Figure 5). Lower tax and nontax revenues are expected to reduce fiscal space by 1.3 percent of GDP while higher interest expenses will absorb another half percent of GDP over the decade (Table 3). Conversely, lower non-SDG public expenditures (1.3 percent of GDP) and higher ODA flows $(0.3$ percent of GDP) almost entirely offset these forces. The decisive factor for the reduced fiscal space is the need to implement a backloaded but more stringent fiscal consolidation than expected before the country was hit by the pandemic. Excluding policy lending, the 20202030 average overall fiscal deficit is projected to narrow from 4.7 percent of GDP in the preCOVID baseline scenario to about 2.5 percent of GDP in the post-COVID projections. In the post-COVID environment, debt sustainability objectives may delay Rwanda's pace to meet its SDGs. The backloaded fiscal consolidation (with narrower fiscal deficits over and beyond the medium term) aims to safeguard Rwanda's debt sustainability. Even if part of the fiscal constraint could be temporarily lifted with additional public borrowing, the authorities are

\footnotetext{
${ }^{10}$ The impact of the recession is somewhat less pronounced on the health and education needs as those largely consist of salaries that gradually adapt to the smaller size of the economy.
} 
committed to bring Rwanda's public debt below 50 percent of GDP (in net present value terms) to meet the debt convergence criterion of the Eastern African Community. Therefore, to attend development needs, the authorities are considering an ambitious medium-term revenue strategy to raise up to 7 percentage points of GDP between 2023 and 2029 (gains of up to 1 percentage point per year relative to baseline projections), which could in turn be mostly invested in SDGs (Figure 6). The MTRS yields are based on a recent IMF Technical Assistance mission that examined Rwanda's tax policies and revenue mobilization potential.

Table 3. Rwanda: Additional Grants Needed to Meet 2030 SDGs 1/

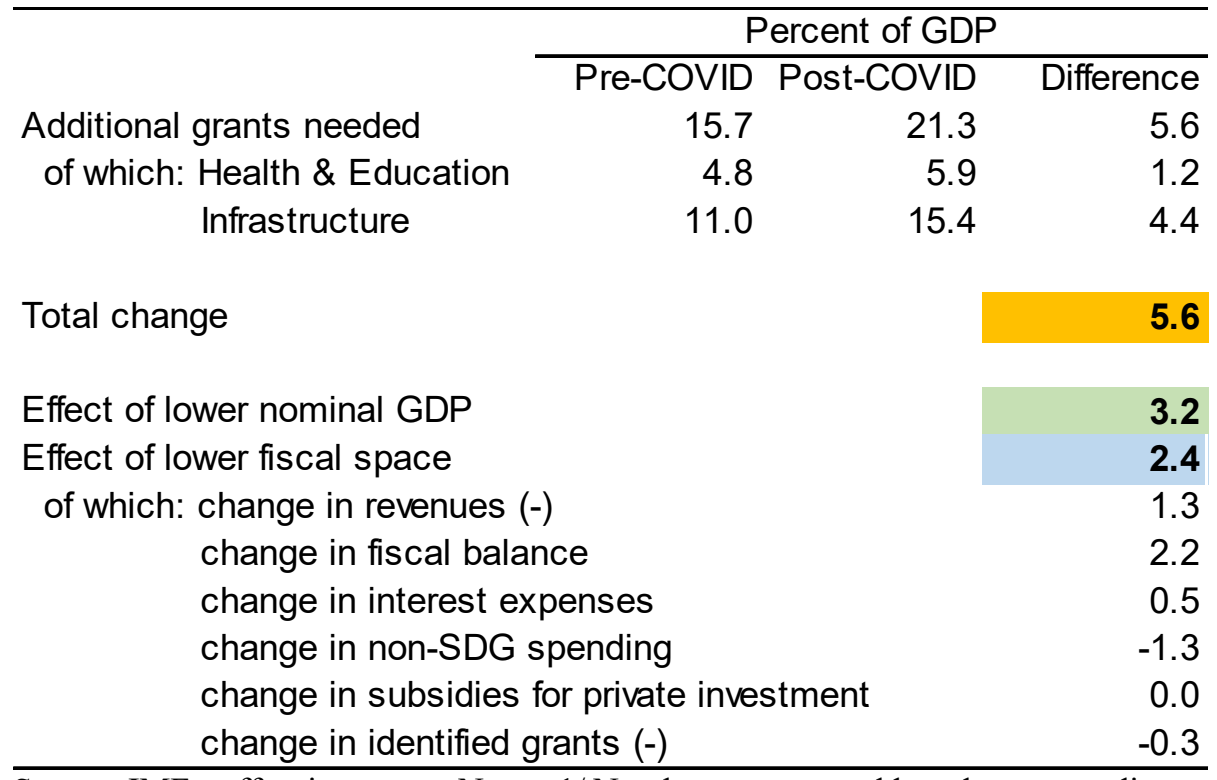

Source: IMF staff estimates Notes: 1 / Numbers may not add up due to rounding.

Figure 5. Rwanda: Changes in Available Fiscal Space to Invest in SDGs, 2020-30 (percent of GDP)

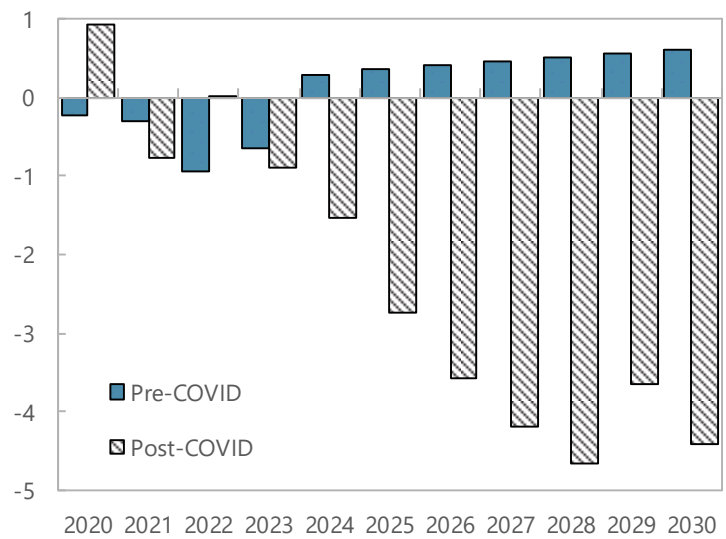

Source: IMF staff estimates
Figure 6. Rwanda: Impact of MTRS on Tax Revenues, 2018-30 (percent of GDP)

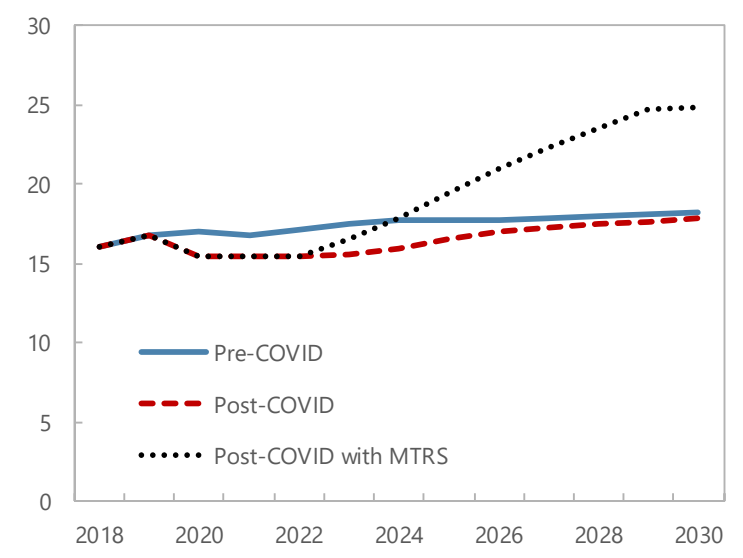

Source: IMF staff estimates 
The pandemic has delayed Rwanda's ability to meet its SDGs by about 5 years and substantially reduced its projected long-term per capita income. Under current policies, Rwanda would meet its SDGs right after 2050. In a counterfactual analysis we estimate that, if the country were able to mobilize all funding needed to close its pre-COVID SDG financing gap by 2030, Rwanda would be able to meet its SDGs by 2035 in the post-COVID environment ( 5 years later than expected). Besides this effect, the pandemic is associated with a projected decline of 18 and 26 percent in Rwanda's 2030 and 2050 per capita income, respectively (Table 4).

Against this background, we assess the impact of the MTRS and several other policy measures that could help to narrow the country's SDG financing gap in the post-pandemic era while lifting per capita income and human capital per worker. The scenario analysis is based on the authorities' policies laid out in December 2020 (IMF 2021) and long-term macroeconomic forecasts using our dynamic financing framework for sustainable development. This exercise not only provides a useful comparison to the pre-COVID results discussed in Section II but it also sheds light on the challenges that have emerged with an unforeseen, exogenous shock of historical proportions like the COVID-19 pandemic.

Ambitious fiscal measures to promote sustainable development have turned even more critical given Rwanda's high debt and limited fiscal space. For instance, enacting a mediumterm revenue strategy that raises the total revenues-to-GDP ratio 7 percentage points above the baseline during 2023-29 could fulfill about one fifth of Rwanda's SDG gap in the postpandemic projections, shortening its development path by 6 years or more. Reallocating one percentage point of GDP in public expenditures towards SDGs and boosting spending efficiency to the level of peers could provide valuable support as well. Together, these fiscal measures could cover more than one quarter of Rwanda's 2030 SDG financing gap, helping the country to meet its SDGs around a decade later (by 2041).

The importance of private investment and additional resources to finance Rwanda's SDGs could not be overstated. Once the economy recovers, if the country were to bring its annual foreign direct investment in line with the top quartile of its peers' distribution, it could gradually attract an extra $23 / 4$ percent of GDP of private resources, which in turn could cover up to one tenth of Rwanda's 2030 SDG financing gap. Altogether, active policies that combine fiscal measures and higher private sector participation could fulfill more than one third of Rwanda's post-pandemic SDG financing gap (21.3 percent of GDP), enabling the country to meet its SDG target by 2040. Nevertheless, even in the scenario with active policies, the pledge to meet its SDGs by 2030 would require about $13 \% / 4$ percentage points of GDP in additional resources annually until then. ${ }^{11}$

\footnotetext{
${ }^{11}$ It is important to recognize that non-financial constraints - including the supply of skilled workers, planning capacity, logistics, and institutional arrangements - may also affect the year when a country meets its SDGs.
} 
Table 4. Rwanda: Dynamic Financing Framework Scenarios, 2020-50 (Post-COVID)

\begin{tabular}{|c|c|c|c|c|c|c|c|c|}
\hline \multirow[b]{2}{*}{ Scenario } & \multirow[b]{2}{*}{$\begin{array}{l}\text { SDGs } \\
\text { met by }\end{array}$} & \multirow[b]{2}{*}{$\begin{array}{c}\text { Additional grants } \\
\text { per year } 1 /\end{array}$} & \multicolumn{2}{|c|}{ Per capita income $2 /$} & \multicolumn{2}{|c|}{ Real GDP growth rate $3 /$} & \multicolumn{2}{|c|}{ Public debt $1 /$} \\
\hline & & & 2030 & 2050 & 2030 & 2050 & 2030 & 2050 \\
\hline A. Post-COVID baseline settings & $>2050$ & 0.0 & 1,089 & 2,893 & 7.2 & 6.5 & 59.2 & 58.6 \\
\hline B. Domestic revenue mobilization & 2044 & 0.0 & 1,088 & 3,073 & 7.2 & 6.7 & 59.2 & 57.1 \\
\hline C. Spending reallocation to SDGs & 2050 & 0.0 & 1,144 & 4,019 & 8.2 & 7.9 & 57.1 & 52.1 \\
\hline D. Combined fiscal measures & 2041 & 0.0 & 1,145 & 4,294 & 8.3 & 8.1 & 57.0 & 51.0 \\
\hline E. Private sector participation & $>2050$ & 0.0 & 1,124 & 3,323 & 7.8 & 7.0 & 57.8 & 55.9 \\
\hline F. Active policies w/o addtl grants & 2040 & 0.0 & 1,179 & 4,601 & 8.8 & 8.4 & 55.8 & 50.1 \\
\hline G. Baseline plus additional grants & 2030 & 21.3 & 1,254 & 4,451 & 9.0 & 8.1 & 53.8 & 51.5 \\
\hline H. Fiscal measures plus grants & 2030 & 15.6 & 1,284 & 5,443 & 9.8 & 8.7 & 52.8 & 48.5 \\
\hline I. Active policies plus grants & 2030 & 13.7 & 1,296 & 5,436 & 10.0 & 8.8 & 52.4 & 48.6 \\
\hline
\end{tabular}

Source: IMF staff estimates.

Notes: 1/ In percent of nominal GDP. 2/ In 2018 USD. 3/ In percent

\section{SDG Financing: The Perils of SCARring}

The pandemic may leave lasting wounds in Rwanda's economy. Economic scarring may be associated with schooling interruptions, protracted unemployment due to skills mismatches, technological disruptions that lead to a permanent decline in contact-intensive sectors, and lower returns to spending on education due to social distancing. To capture those, we calibrate two parameters of the endogenous growth model in Rwanda's dynamic financing framework: the human capital depreciation rate and the elasticity of new human capital formation to education spending. We conjecture that economic scarring accelerates human capital depreciation and lowers the elasticity of new human capital formation to education spending for about five years, at declining rates, and with lasting negative spillovers to total factor productivity growth. In these circumstances, Rwanda's stock of human capital could end the decade almost 24 percentage points below pre-COVID projections (Figure 7) and its real GDP growth rate could drop below 6 percent (Figure 8).

With economic scarring, Rwanda's 2030 SDG financing gap would widen. The scarring would entail adjustment costs for firms and workers, including through costly resource reallocation across sectors and exit of discouraged workers from the labor force (IMF 2020d). These factors could reduce productivity and delay a firm economic recovery. Sluggish growth would be associated with reduced revenues, further compressing fiscal space for public investment in SDGs. Following the decomposition presented in Section IV, the dynamic financing framework suggests that this illustrative scenario with economic scarring could lead to additional financing needs of $1-1 \frac{1}{2}$ percentage points of GDP, mostly due to higher infrastructure needs (relative to the smaller size of the economy), pushing Rwanda's 2030 SDG financing gap towards $22 \frac{1}{2}$ percent of GDP per year. 
Figure 7. Rwanda: Impact of Scarring on Human Capital Per Worker, 2018-50 (index, 2019=100)

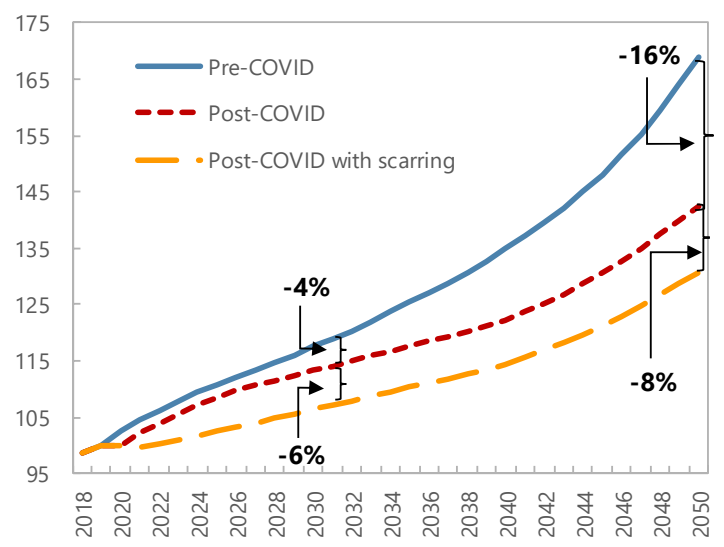

Figure 8. Rwanda: Impact of Scarring on Real GDP Growth Rates, 2018-50 (percent)

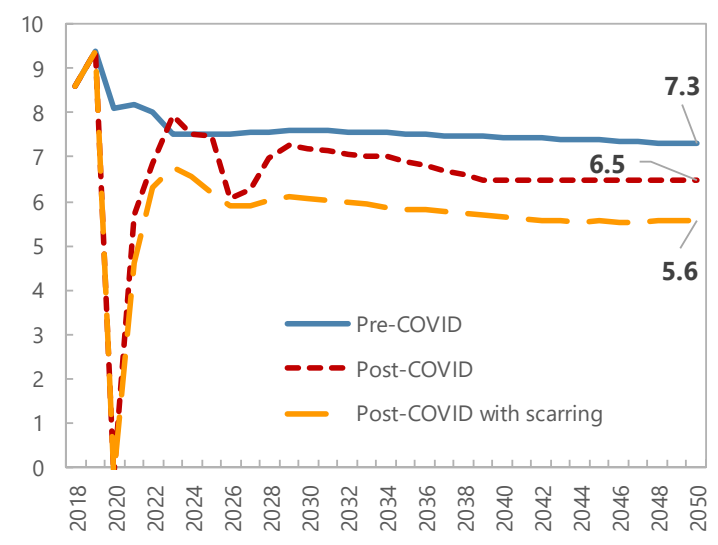

To cope with potential scarring, Rwanda should promote policies that decisively support its SDGs. The illustrative scarring has the potential to gradually shave almost one quarter of Rwanda's projected per capita income in the long run (Figure 9). Enacting active policies would more than offset these losses, eventually pushing Rwanda's per capita income above pre-pandemic projections. The pursuit of SDGs through active policies would have an even larger impact on Rwanda's stock of human capital per worker, substantially offsetting any pushback from pandemic scarring (Figure 10). Such finding is critical because human capital per worker is a key source of Rwanda's long-term economic growth. Thus, besides the fiscal measures, the provision of appropriate conditions for private investment in areas that lack attractiveness and adequate public resources, such as health and education, should be seen as a priority in Rwanda's development strategy.

Figure 9. Rwanda: Impact of Active Policies on Per Capita Income, 2018-50 (in 2019 US\$)

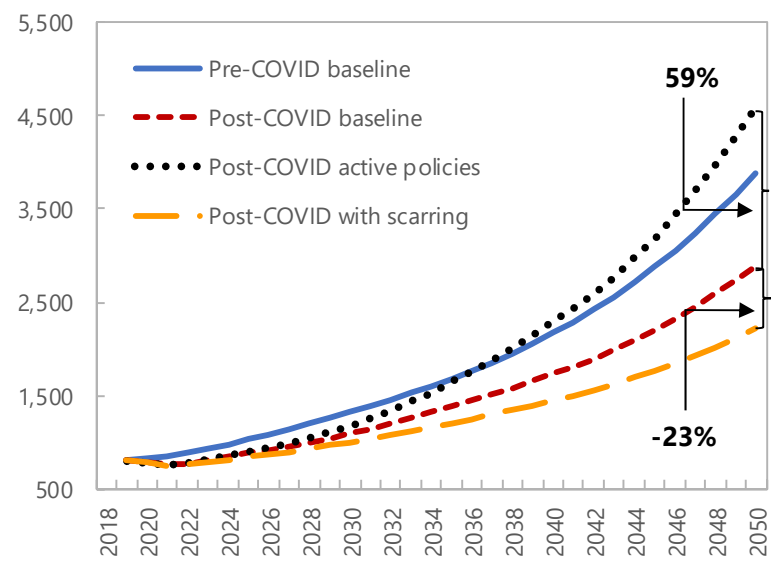

Figure 10. Rwanda: Impact of Active Policies on Human Capital Per Worker, 2018-50 (index, 2019=100)

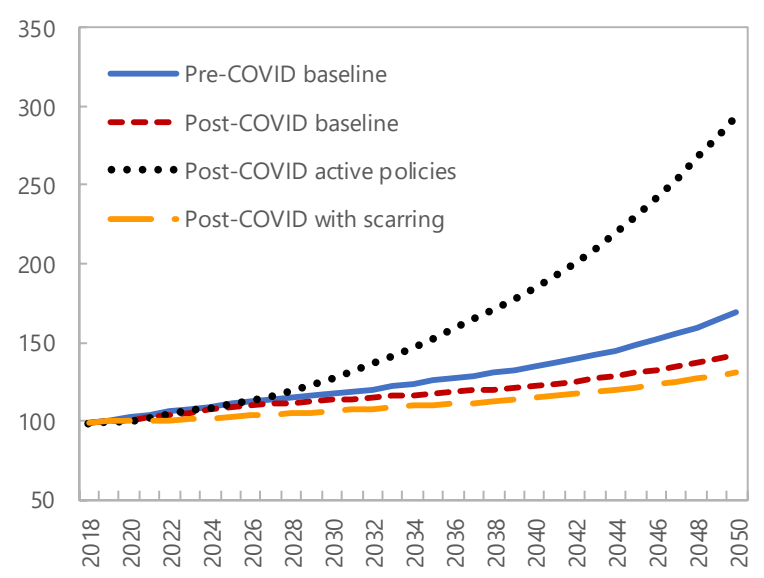




\section{CONCLUding ReMARKS}

In this paper we introduce a dynamic financing framework to estimate the impact of the COVID-19 pandemic on Rwanda's SDG financing gap. The framework helps economists and policymakers to assess the feasibility of meeting SDGs within a given projection horizon in an inter-temporally and economically coherent way. The framework is flexible enough to permit the assessment of different financing options in alternative macroeconomic scenarios and using various policy levers, including domestic revenue mobilization, private sector funding, and support from the international community. In particular, the framework gauges whether and how the SDGs can realistically be achieved by 2030 under current policies and, if not, by when they could be. Last, but not least, the dynamic financing framework allows for assessing the extent of economic scarring by estimating the pandemic impact on longterm growth and associated SDG financing gap in stylized scenarios.

Using this novel dynamic financing framework, we estimate Rwanda will need additional resources in the order of 21 1/4 percent of GDP per year to meet its SDGs by 2030. This compares with a pre-pandemic SDG financing gap of 15.7 percent of GDP per year using the same model. The additional needs could be $1-1 \frac{1}{2}$ percent of GDP larger in a scenario with long-term economic scarring. The widening of Rwanda's SDG financing gap post-pandemic can be mostly attributed to lower GDP and reduced fiscal space. The pandemic is expected to impose output losses to the tune of 10 percent in real terms, which translates into additional SDG financing gap of 3.2 percent of GDP per year until 2030 (mostly reflecting higher infrastructure costs relative to the smaller size of the economy). Rwanda's commitment to safeguard debt sustainability entails a backloaded fiscal adjustment that substantially narrows the country's overall fiscal deficit. The tighter stance reduces Rwanda's annual fiscal space to invest in SDGs, on average, by 2.4 percent of GDP over this decade.

Closing Rwanda's post-pandemic SDG financing gap will require a combination of ambitious fiscal measures, private sector participation, and additional resources. Under current policies, Rwanda would meet its SDGs right after 2050. Active policies that combine fiscal measures and higher private sector participation could fulfill more than one third of Rwanda's financing gap, enabling the country to meet its SDG targets by 2040. Nevertheless, even in the scenario with active policies, the pledge to meet its SDGs by 2030 would require about $13 \frac{3}{4}$ percentage points of GDP in additional resources annually until then. ODA, mainly on concessional terms, would still be critical to help Rwanda meeting its SDGs.

Ambitious fiscal measures to enhance domestic revenue mobilization and boost spending efficiency have turned even more critical post-pandemic. By increasing government resources, they serve the twin purposes of closing SDG financing gaps and reducing public debt consistent with Rwanda's fiscal consolidation objectives. Our estimates show that enacting a medium-term revenue strategy that gradually raises the total revenues-to-GDP ratio by about 7 percentage points above the baseline during 2023-29, reallocating one percentage point of GDP in public expenditures towards SDGs, and boosting spending efficiency to the level of peers could cover more than one quarter of Rwanda's 2030 SDG financing gap, helping the country to meet its SDGs around a decade later (by 2041). 
Attracting private investment and additional resources to finance Rwanda's SDGs cannot be overstated. Once the economy recovers, if the country were to bring its annual foreign direct investment in line with the top quartile of its peers' distribution, it could gradually attract an extra $23 / 4$ percent of GDP of private resources, which in turn could cover up to one tenth of Rwanda's 2030 SDG financing gap. Polices to attract private investment should aim at continuing to strengthen Rwanda's business climate and governance, developing a solid pipeline of "bankable" infrastructure projects, generating an attractive risk-return profile for the private sector on a project-by-project basis through public-private partnerships, and providing government guarantees ("de-risking") with due regard to fair and proportional distribution of risk and return among public and private participants.

Financing Rwanda's SDG cannot be achieved without additional support from development partners, including by securing additional concessional resources from bilateral and multilateral donors, leveraging existing resources to finance de-risking initiatives (blended finance), and unlocking untapped resources from institutional investors (e.g. pension and mutual funds, insurance companies) and private philanthropies. 


\section{References}

Akanbi, O., D. Bartolini, S. Cerovic, H. Chai, R. Fenochietto, N. Nersesyan, and R. Perrelli, 2021, "A Post-Pandemic Assessment of Sustainable Development Goals: Background Notes," IMF Staff Discussion Note (forthcoming), International Monetary Fund, Washington, DC.

Atolia, M., B.G. Li, R. Marto, and G. Melina, 2019, "Investing in Public Infrastructure: Roads or Schools?", Macroeconomic Dynamics, First View, pp 1-30. https://doi.org/10.1017/S1365100519000907.

Benedek, D., E. Gemayel, A. Senhadji, and A. Tieman, 2021, “A Post-Pandemic Assessment of Sustainable Development Goals," IMF Staff Discussion Note (forthcoming), International Monetary Fund, Washington, DC.

Bartolini, D., and K. Hellwig, 2021, “A Long-Term Framework for Assessing SDG Financing Strategies," IMF Working Paper (forthcoming), International Monetary Fund, Washington, D.C.

Berg, A., R. Portillo, S-C. S. Yang, and L-F. Zanna, 2012, "Public Investment in ResourceAbundant Developing Countries," IMF Working Paper 12/274, International Monetary Fund, Washington, D.C.

Buffie, E.F., A. Berg, C. Pattillo, R. Portillo, and L.-F. Zanna, 2012, "Public Investment, Growth, and Debt Sustainability: Putting Together the Pieces," IMF Working Paper 12/144, International Monetary Fund, Washington, D.C.

Gaspar, V., D. Amaglobeli, M. Garcia-Escribano, D. Prady, and M. Soto, 2019, "Fiscal Policy and Development: Human, Social, and Physical Investment for the SDGs," IMF Staff Discussion Note 19/03, International Monetary Fund, Washington, DC.

IMF, 2015, “Making Public Investment More Efficient,” International Monetary Fund, Washington, D.C.

—, 2019, "Rwanda-Staff Report for the 2019 Article IV Consultation and Request for a Three-Year Policy Coordination Instrument,” IMF Country Report 19/211, International Monetary Fund, Washington, DC.

— , 2020, World Economic Outlook-A Long and Difficult Ascent (October 2020). International Monetary Fund, Washington, DC.

— , 2020b, "Rwanda-First Review under the Policy Coordination Instrument and Monetary Policy Consultation," IMF Country Report 20/9. International Monetary Fund, Washington, DC. 
— 2020c, "Rwanda—Request for Disbursement under the Rapid Credit Facility," IMF Country Report 20/115, International Monetary Fund, Washington, DC.

— 2020, "Rwanda—Request for Disbursement under the Rapid Credit Facility," IMF Country Report 20/207, International Monetary Fund, Washington, DC.

—_, 2021, "Rwanda—Third Review under the Policy Coordination Instrument," IMF Country Report 21/1, International Monetary Fund, Washington, DC.

Irwin, T., S. Mazraani and S. Saxena, 2018, "How to Control the Costs of Public-Private Partnerships," How-to Note 18/04, International Monetary Fund, Washington, D.C.

Prady, D., and S. Mouhamadou, 2019, "The Spending Challenge for Reaching the SDGs in Sub-Saharan Africa: Lessons Learned from Benin and Rwanda," IMF Working Paper 19/270, International Monetary Fund, Washington, DC.

Redifer, L., E. Alper, N. Meads, T. Gursoy, M. Newiak, and A. Thomas, 2020, “ The Development Path Less Traveled: The Experience of Rwanda," AFR Departmental Paper Series, 20/10, International Monetary Fund, Washington, DC.

United Nations, 2019, "World Population Prospects 2019," Department of Economic and Social Affairs, Population Division. https://population.un.org/wpp/Publications/.

World Bank, 2020. Global Economic Prospects (October 2020), World Bank, Washington, DC.

World Bank, 2021. Global Economic Prospects (January 2021), World Bank, Washington, DC.

World Bank, 2021, Rwanda Economic Update (January 2021), World Bank, Washington, DC. 